\title{
The Origins of the Catholic Charismatic Renewal in the United States: The Experience at the University of Notre Dame and South Bend (Indiana), 1967-1975
}

\author{
Valentina Ciciliot
}

The Catholic charismatic renewal (CCR) began in February 1967, at Pittsburgh's Duquesne University, Pennsylvania, when a history professor, William (Bill) Storey, and a graduate student, Ralph Kiefer, were baptized in the Holy Spirit in an Episcopalian charismatic prayer group. Through personal contacts, the experience of the Holy Spirit soon spread to the University of Notre Dame, then to Michigan State University (East Lansing, MI), and to the University of Michigan (Ann Arbor, MI), and many other parts of the United States. ${ }^{1}$ At ever-increasing numbers of locations, regular prayer meetings, usually weekly, and sometimes covenant communities developed, often with many college students participating from the outset.

Thanks to exponential growth within the first decade, the movement extended beyond national borders, creating institutional structures able to offer coordination and guidance, as well as legitimacy. In fact, the North American leadership that arose in the 1970s was able to establish successful networks, long-term institutions, and a theological soundness that shaped and consolidated the CCR worldwide. Early Catholic charismatic leaders shared several commonalities. They were middle-class, educated people, who had all

1 See Susan A. Maurer, The Spirit of Enthusiasm: A History of the Catholic Charismatic Renewal, 1967-200o (Lanham, MD: University Press of America, 2010). Among memoirs and first studies: Kevin and Dorothy Ranaghan, Catholic Pentecostals (Paramus, NJ: Paulist Press, 1969); Edward O'Connor, The Pentecostal Movement in the Catholic Church (Notre Dame, IN: Ave Maria Press, 1971); Joseph H. Fichter, The Catholic Cult of the Paraclete (New York: Sheed and Ward, 1975); Richard J. Bord and Joseph E. Faulkner, The Catholic Charismatics: The Anatomy of a Modern Religious Movement (University Park, PA: Pennsylvania University Press, 1983); René Laurentin, Catholic Pentecostalism (Garden City, NY: Doubleday, 1977); Meredith B. McGuire, Pentecostal Catholics: Power, Charisma and Order in a Religious Movement (Philadelphia: Temple University Press, 1982); Patty Gallagher Mansfield, As By a New Pentecost: The Dramatic Beginning of the Catholic Charismatic Renewal (Steubenville, OH: Franciscan University Press, 1992). 
been raised in the pre-Vatican II Church. Primed by the run-up to Vatican II, they were expecting renewal and change in the Church. Through the Cursillo movement, in which most of them were trained, they already saw themselves as possible agents of that change, in the role of lay activists. Most of them were intellectuals. Thus, they could write effectively, give talks, identify patterns, and recognize subtle trends developing. Thanks also to the relationships with leaders of other Christian denominations which had already experienced such a renewal they immediately elaborated various opinions about what the CCR was and where it should go. As academics and students - most of them teachers or graduates of Notre Dame between 1965 and 1969 - they approached different viewpoints with an openness to discussion, thus avoiding, at least at the beginning, the development of secessionist groups, as instead happened in other churches.

Since the origins and the early leadership of the CCR can be traced to the American Midwest, this chapter will concentrate its analysis on the Catholic charismatic experience in Indiana, at the University of Notre Dame and in South Bend, focusing on the origin narrative, the individuals involved, the creation of institutional structures, and the initial criticism which Catholic charismatic leaders received. However, the purpose of this chapter is not only to provide a general description of the characteristics and protagonists of the CCR at its origins, but also to provide a more precise historical contextualization of the wider movement.

Scholars, especially American specialists, have focused on the CCR's selfconfident lay component and the wider search for religious renewal. American historian James O'Toole, for example, in his history of American Catholics, interprets the emergence of the CCR as one of the consequences of Vatican II's encouragement to lay people to worship and pray on their own, as a way of 'personalizing of faith', as with the Cursillo, the Christian family movement, and Bible study groups. ${ }^{2}$ Jay Dolan, on the other hand, attributes the origins of the CCR to the general historical context of American society, describing it as a phenomenon that Vatican II 'never envisioned and never considered', suggesting that it emerged 'out of the broader spiritual renewal taking place in American society during the 1960s and 1970s, a time when millions of Americans turned to new forms of religious expression in order to fill a need in their lives. ${ }^{3}$ As a matter of fact, both the growing sense of personal autonomy

2 James M. O'Toole, The Faithful: A History of Catholics in America (Cambridge, MA: Belknap Press of Harvard University, 2008), 227-30.

3 Jay P. Dolan, The American Catholic Experience: A History from Colonial Times to the Present (Notre Dame, IN: University of Notre Dame Press, 1992), 433. 
among American Catholic laity ${ }^{4}$ (associated with the concept of 'Catholic adulthood' developed after Vatican II, as O'Toole suggests), and the search for spiritual and social renewal in the Church (explained with reference to the specific American culture of the time, as Dolan argues), were central influences on the emergence of the CCR. ${ }^{5}$ As it turned out, the Cursillo background of many early Catholic charismatic leaders who were connected with Notre Dame had already created a link between this new independent role for laypeople and the promotion of interior spiritual renewal.

There was a pervasive sense of change within American society in the 196os and early 1970s, when ideas of spiritual renewal and communal life circulated and the broader youth culture was transformed by the sexual revolution and pacifism. ${ }^{6}$ The search for an alternative spirituality was compelling for many. That impulse was evident among the Jesus People movement and in the hippie subculture, and it influenced the Catholic Church as well. In fact, to a certain extent the CCR was one of the Catholic responses to these changing decades. Just as the counterculture sanctioned spontaneous and emotional public display, so too charismatic worship allowed Catholics to express their spirituality and faith in a much less structured way, free from the authoritative control of liturgical prescriptions. The CCR was thus influenced by those changes and it brought into the Catholic Church the spontaneity, the sense of community, the emotionality of those years, even while anchoring these new elements to the ecclesiastical tradition and thus providing a sense of continuity that the Catholic Church urgently needed in the post-conciliar decades. The ecclesiastical hierarchy would progressively accept the charismatic movement not only because of its lack of interest in the hottest social and political issues (pacifism, abortion), but also because it embraced certain grassroots needs (greater freedom and independence of the laity, greater individualism in the encounter with the divine) along with a certain spirit of the time that, if properly guided, could prove fruitful. In other words, a certain liturgical-sacramental, pastoral

4 William V. D'Antonio, James D. Davidson, Dean R. Hoge, and Ruth. A. Wallace (eds), American Catholic Laity in a Changing World (Kansas City, MO: Sheed and Ward, 1989).

5 Robert Wuthknow (ed.), 'I Come Away Stronger': How Small Groups Are Shaping American Religion (Grand Rapids, MI: Eerdmans, 1994).

6 Although they do not mention the CCR, see Mark M. Massa, The American Catholic Revolution: How the Sixties Changed the Church Forever (Oxford: Oxford University Press, 2010); Robert S. Ellwood, The Sixties Spiritual Awakening: American Religion Moving from Modern to Postmodern (New Brunswick, NJ: Rutgers University Press, 1994), 1-233. See also the sociological studies conducted in 1973 on different North American movements, including the CCR, in Luther P. Gerlach and Virginia H. Hine (eds), Lifeway Leap: The Dynamics of Change in America (Minneapolis, MN: University of Minnesota Press, 1973). 
and theological openness was acceptable, without however a social and political progressivism feared by some segments of the North American Catholic Church and the Vatican. This highly nuanced appreciation of the place of the CCR in the Church shows why it is not possible to use the 'liberal' and 'conservative' Catholic labels to explain the movement. It also illustrates the dynamics of legitimization. On the one hand, the hierarchy was unwilling to close the door to something that was becoming too large and too powerful; on the other hand, the Catholic charismatic leaders were eager to be faithful to the Church from the beginning, even at the cost of sacrificing the most advanced ecumenical experiments, the most 'pentecostal' emotionality and some degree of theological audacity.

Finally, despite the obvious fact that this post-Vatican II American Catholic context is fundamental for understanding the origins of the CCR, it would be a mistake to underestimate the influence of the charismatic renewal in other Christian denominations and the importance of interactions among charismatics. Throughout this chapter, it is clear that synergies between Catholics and Protestants (mainly Episcopalians, but Pentecostal and interdenominational groups as well) profoundly influenced the initial visions and goals of the CCR. The alliance between Catholic charismatics and the Fountain Trust, which was born as a service agency for the renewal in Great Britain, was another important aspect. ${ }^{7} \mathrm{~A}$ historical understanding of Protestant charismatic revivals taught these Catholics how to avoid divisiveness and factionalism, which moved them to look for the ecclesiastical hierarchy's consent as one of their priorities. Additionally, ecumenical relations among charismatic leaders (later constrained by Catholic theologians who feared a drift toward denominationalism) contributed to the creation of an international charismatic scenario which favoured the development of the CCR globally. ${ }^{8}$

\section{$1 \quad$ Early Origins}

The Pittsburgh 'Duquesne weekend' of 17-19 February 1967 marked the beginning of the Catholic charismatic renewal. While there were certainly Catholic

7 Peter Hocken, Streams of Renewal: The Origins and Early Development of the Charismatic Movement in Great Britain (Exeter: Paternoster Press, 1986), 121-7; Connie Ho Yan Au, Grassroots Unity in the Charismatic Renewal (Eugene, OR: Wipf and Stock, 2011).

8 See, for example, the second Malines document, Léon Joseph Suenens, Ecumenism and Charismatic Renewal: Theological and Pastoral Orientations (Ann Arbor, MI: Servant Books, 1978). 
individuals who experienced baptism in the Spirit prior to that event in a variety of forms and circumstances, that weekend is conventionally understood to be the beginning of the widespread mass movement that surged throughout the United States and eventually around the world. This quickly became the founding myth, recurring in many accounts, such as books by Edward O'Connor and Kevin and Dorothy Ranaghan, ${ }^{9}$ and the narrative was permanently consolidated by the testimony of Patti Gallagher Mansfield, a key eye-witness and official spokeswoman. Her version of the story, As By a New Pentecost (1992), was republished to mark the 2017 golden jubilee of the CCR. ${ }^{10}$

Fresh analysis of these origins demonstrates the significance of a complex web of interdenominational relationships. During the National Cursillo Convention in 1966 a group of people in Pittsburgh met Steve Clark and Ralph Martin, who at that time were staff members of St Joseph parish in East Lansing, Michigan, and deeply involved in the Cursillo movement. Clark and Martin suggested the reading of John Sherrill's The Cross and the Switchblade (1963), the story of Episcopalian David Wilkerson's ministry among young gang members and drug addicts in New York City. By chance, one of those in Pittsburgh, Ralph Kiefer, an instructor in the theology department at Duquesne University, was reading another of Sherrill's books, They Speak with Other Tongues (1965), on glossolalia and the experience of the Holy Spirit, and was profoundly touched by the content. Those inspiring readings spurred Kiefer and others to look more deeply into the baptism in the Spirit. They contacted an Episcopalian priest who had come to Duquesne once for a lecture, William Lewis, rector of Christ Church parish in Pittsburgh. The decision to approach an Episcopalian was not surprising, since the Episcopal Church was experiencing a well-publicized charismatic revival and it would have been difficult to approach denominational Pentecostals because of their anti-Catholicism. Lewis told them that a parishioner, Betty Schoemaker, held a prayer meeting once a week in her house, a model to imitate. On 13 January 1967, a group from Duquesne met for their own prayer meeting, at the home of Florence Dodge. At a second meeting Kiefer and another instructor in theology at Duquesne, Patrick Bourgeois, participated, and they were prayed with for baptism in the Holy Spirit. The following week they laid hands on two Catholic colleagues (presumably including William Storey, a Duquesne history professor). ${ }^{11}$ At that time Patti Gallagher (not yet Mansfield, her married name) was a French major at Duquesne. She was a member of the Chi Rho Society, a Scripture study group at the university,

9 O'Connor, The Pentecostal Movement in the Catholic Church; Ranaghan, Catholic Pentecostals.

10 The golden jubilee edition of Mansfield's text was issued by New Life Publishing in 2016 .

11 Ranaghan, Catholic Pentecostals, 6-23. 
which organized the February 1967 weekend retreat at 'The Ark and the Dove' retreat house. It was structured as a time for prayer and meditation over the first four chapters of the Acts of Apostles, and in preparation Sherrill's book on David Wilkerson was given to participants. About 30 students and faculty members, including Storey and Kiefer, participated. It was Gallagher's firstever retreat and she was uncomfortable. During the meeting the participants invoked the Holy Spirit. Gallagher, together with David Mangan (who eventually provided his own important testimony to these events) and others, experienced the dramatic presence of the Holy Spirit and charismatic gifts, such as speaking in tongues, prophecy, and healing. ${ }^{12}$

After that weekend retreat, the participants spread news of the experience among friends and classmates. In March 1967 Martin and Clark arrived at the Duquesne campus to discuss their understanding of the Holy Spirit, inviting Gallagher to join them in their lay ministry in Michigan after graduation. Martin and Gallagher struck up a friendship, and he encouraged her role of providing an 'official' testimony. For example, they attended a prayer meeting in New York City with a group of students from Fordham University, where at Martin's urging she shared her account of the Duquesne weekend. That summer Gallagher spent some time working with Martin's campus ministry at Michigan State University and also travelled to the First Reformed Church in Mount Vernon, New York City, pastored by Harald Bredesen, a Lutheran who visited Duquesne after Easter 1967. He had been baptized in the Spirit in 1946 and had personal contacts with Sherrill and Wilkerson. ${ }^{13}$

These initial accounts have inevitably been affected by oral layering and successive written codifications, not necessarily unintentional. Several specific founding elements of the CCR can be recognized from the very beginning: a stance in favour of reforming the Roman Catholic Church, a desire for a more intense spiritual encounter with the divine, a practical ecumenism, and the networking of Catholic intellectuals. Indeed, it was thanks to personal relationships that the religious experience that occurred in Pittsburgh soon shifted to South Bend and the University of Notre Dame. Several members of the Duquesne faculty had done their graduate studies at Notre Dame, and likewise several graduate students at Notre Dame had been undergraduates at Duquesne. Through Bertil (Bert) Ghezzi, a graduate student at Duquesne and later a doctoral candidate in history at Notre Dame, people in South Bend had heard (as early as January 1967) the news that friends were about to join

\footnotetext{
12 Mansfield, As By a New Pentecost, 22-30.

13 Maurer, The Spirit of Enthusiasm, 27-33. See also Mansfield, As By a New Pentecost, 34-6o; Ranaghan, Catholic Pentecostals, 33-7.
} 
a charismatic prayer group and seek baptism in the Holy Spirit in Pittsburgh. In mid-February, Kiefer came to South Bend and spent a weekend with the Ranaghans. Kevin Ranaghan was at that time a doctoral candidate in the theology department, and he and his wife Dorothy were promoters of liturgical renewal. After 'The Ark and the Dove' retreat, Kiefer called the couple, telling of the 'wonders' of the Duquesne weekend. ${ }^{14}$ It is also likely that during Cursillo planning meetings at the South Bend home of Notre Dame professor of physics Paul DeCelles, who eventually became one of the founders of the People of Praise community, participants discussed the Duquesne events. ${ }^{15}$

The Ranaghans decided to hold a prayer meeting at their house on 4 March 1967. The following night another meeting at the home of Bert and Mary Lou Ghezzi resulted in the laying on of hands on several Notre Dame people, and most of them received the gift of tongues. Eager to know more about the baptism in the Spirit, they attended a meeting on 13 March 1967, in the home of Ray Bullard, a deacon at Calvary Temple in South Bend (Assemblies of God) and president of the local chapter of the Full Gospel Businessmen's Fellowship International (FG BMFI), an inter-denominational group of laymen who shared the experience of baptism in the Spirit. These 'training' meetings occurred prior to the first Catholic pentecostal meeting at the Ranaghans' home a few days later with about 20 people, including Fr. Edward O'Connor. Public meetings on the Notre Dame campus started soon thereafter, and Bishop Leo Pursley of Fort Wayne-South Bend was immediately informed. ${ }^{16}$

Another key event in the narrative of the origin of the CCR was the so-called Michigan State weekend. After Easter 1967, on 7-9 April, people in Notre Dame organized a weekend retreat with some friends from Michigan State University, such as Martin and Clark who had been students at Notre Dame in $1963-65$. Both of them had maintained strong ties with a number of Notre Dame / South Bend people involved in the Cursillo. There were about 40 participants from Notre Dame and 40 from Michigan State. This retreat, along with subsequent weekly public charismatic meetings on Notre Dame campus that grew very large, was publicized in several local and national articles, such as in two Notre Dame publications, The Scholastic student magazine and The Observer student newspaper, and in The South Bend Tribune and The National Catholic

\footnotetext{
14 Ranaghan, Catholic Pentecostals, 39.

15 O'Connor, The Pentecostal Movement, 46.

16 O'Connor, The Pentecostal Movement, 52. The liaison between the nascent Catholic charismatic group at Notre Dame and Bishop Pursley was O'Connor; see correspondence of Edward O'Connor [CEOC], passim, University of Notre Dame Archives [UNDA].
} 
Reporter. ${ }^{17}$ This widespread publicity gave the meetings high visibility across the country, and aroused the interest of many who would arrive at Notre Dame for the university's upcoming summer session. In addition, many students returned home for the summer after the semester ended and spread the news in their home towns. Participants in the Michigan State weekend continued to keep in frequent communication with one another, and early participants in the renewal often travelled to discuss what was happening, share experiences and, above all, pray together. This pattern of travel and gathering together, regionally and nationally, became one of the chief characteristics of the CCR.

Doug Wead, a pentecostal leader, was sent to the prayer meeting at Notre Dame by his father, the pastor of Calvary Temple, to understand this 'paradox of "Catholic Pentecostals" '.18 In his somewhat sensationalistic words it is possible to get a glimpse of the pentecostal reaction towards what was going on within the Catholic Church, that of excitement and incredulity:

There was an excitement in my first charismatic Catholic experience that I have never recaptured. For me, there was at least one unique factor. Somehow, God had changed. Suddenly. He was more than a conservative Republican from northern Indiana. He became a God of many people, people of different cultural, ideological and racial backgrounds. This university community in which I first saw the Catholic renewal was urban and liberal - the opposite pole ideologically. Outside of football enthusiasm for the Fighting Irish [nickname for the University of Notre Dame's sports teams] we had nothing in common. Yet, while I was busy across town working at Calvary Temple (which I assumed to be God's South Bend headquarters), God had been very busy at Notre Dame. ${ }^{19}$

In fact, a borrowing from the Protestant world, and to all appearances quite far removed from typical Catholic spirituality, was being experienced and reworked by Catholics who were determined not to abandon their affiliation with their Church.

On Sunday, 15 October 1967, a number of Catholics from Michigan gathered together for a day of prayer and study in Williamston, a small town east of Lansing. This gathering became the first of a series of Michigan 'Days of

17 The first article was Dan Murray, 'As the Devil Left, I Smelt Clearly the Odor of Burning Sulphur', The Scholastic (14 April 1967), 18-20.

18 Doug Wead, Catholic Charismatics: Are They For Real? (Carol Stream, IL: Creation House, 1973), 5 .

19 Wead, Catholic Charismatics, 10. 
Renewal' in Williamston, a successful format which was soon copied nationally: a large group of charismatics gathering for a Bible vigil, sharing session, a talk, workshop, supper, and prayer meeting. ${ }^{20}$ To the Sunday renewal days were soon added Saturday workshops, reserved for leaders of prayer groups, to address pastoral concerns, which later developed into the annual Catholic charismatic leaders' conference in Ann Arbor. In March 1969, a newsletter with the aim of summarizing the discussions among leaders was launched. Its scope was broadened in June 1970 to serve Catholic charismatics throughout North America, and in the following year it became the quasi-official magazine of the CCR, renamed New Covenant.

At Notre Dame in 1967, following spring and summer's 'wildfire' experience of very rapid growth and the focus of a national spotlight on what were termed 'Catholic pentecostals', a reduction in the number of public prayer meeting participants caused the gatherings to move off-campus, to Paul and Jeanne DeCelles's house, with more people from South Bend involved. At the same time, in spring 1968 , more intense charismatic efforts were feasible on the Notre Dame campus when two graduates from the university, James (Jim) Byrne and Peter Edwards, friends and roommates, decided to stay at Notre Dame and devote themselves to full-time work on behalf of the CCR on a voluntary basis. Meanwhile, in autumn 1967 Martin and Clark had moved from Michigan State University and the charismatic group in Lansing to the University of Michigan in Ann Arbor. They were joined that spring by Notre Dame graduating seniors Gerry Rauch and Jim Cavnar, already involved in the Cursillo and the Antioch Weekend. In Ann Arbor the four men worked in cooperation with the Newman Center on the university campus, establishing the initial nucleus of the first covenant charismatic community. ${ }^{21}$ Interdenominational contacts increased. Throughout the early days, some Catholic leaders began to appear as speakers at FGBMFI conventions, worked with the Inter-Church Team Ministry (an interdenominational group of ministers who promoted the charismatic renewal in the mainline Protestant churches), and participated in other nonCatholic events, making the CCR visible within an ecumenical context. Only three years after the Duquesne weekend, the experience of baptism in the Spirit which began among a few Catholics was becoming a potent movement

20 Bert Ghezzi, 'The Days of Renewal in Michigan' (19 December 1969), Archives of Diocese of Lansing: Bishop Zaleski, NсС в Committee on Doctrine, George Martin Correspondence, Pentecostal Movement.

21 For further developments in other areas of the country see James Connelly, 'The Charismatic Movement, 1967-1970', in Kevin and Dorothy Ranaghan (eds), As the Spirit Leads Us (Paramus, NJ: Paulist Press, 1971), 221-6. 
within the Catholic Church, organized and equipped with bureaucratic structures functioning in an increasingly confident way.

The Michigan State weekend of April 1967 became an annual celebration in the form of a conference on the charismatic renewal in the Catholic Church at Notre Dame - and in retrospect the weekend was known as the 'first international Catholic charismatic conference'. Described by Wead as a 'theological catalyst', this yearly conference grew to become multi-layered events by which Catholic charismatics fostered and maintained their existence in a selfconscious way. ${ }^{22}$ The conferences were held annually at Notre Dame until the 1980s, with only two exceptions in 1975 (Rome) and 1977 (Kansas City), and were internationally respected events during which charismatic spirituality could be spread both to committed participants and to newcomers. They were also an opportunity for theologians and a wide variety of charismatic leaders to meet together, discussing the progress of the movement and their deepening understanding of its patterns and impact, and devising ways to legitimize their evolving experience and structures within the tradition of the Catholic Church. The gathering was a model for many other conferences around the world, in a sort of a duplication of Notre Dame 'at home.. 23

The third Notre Dame conference, on 25-27 April 1969, witnessed the inception of early formal structures. The Notre Dame community (including people from South Bend) took charge of the event, with Byrne as the main organizer. In some ways it followed the pattern of the Catholic charismatic leaders' conference held in Ann Arbor a few months earlier, in January 1969, and leaders from Ann Arbor were also actively involved. Conference participants numbered more than 500 and the non-Catholic keynote speakers included David du Plessis (Pentecostal) and Graham Pulkingham (Episcopalian). The event also showed that CCR prayer groups and communities all across North America had started looking both to Notre Dame / South Bend and to Ann Arbor for leadership and pastoral guidance, and leaders in both locations began deliberately to assume these roles. They proposed the creation of a Communication Center in South Bend, that would publicize the CCR, sending printed and taped material around the world. They also established the

\footnotetext{
22 Wead, Catholic Charismatics, 114.

23 Kevin and Dorothy Ranaghan, Catholic Pentecostals Today (South Bend, IN: Charismatic Renewal Services, 1983), 47 .
} 
Catholic Charismatic Renewal Service Committee (CCRSC, later renamed National Service Committee), to provide services such as organizing conferences, leadership training, publishing the New Covenant newsletter and other promotional literature, and working to keep Catholic charismatics connected to one another. Composed of eight leaders from the Midwest - Jim Byrne, Kevin Ranaghan, Edward O'Connor, George Martin, Ralph Martin, Steve Clark, George Kosicki, and Bert Ghezzi - the CCRSC was soon joined by a larger Advisory Committee of about 30 leaders of Catholic pentecostal prayer groups from around the country 'to ensure a broader national voice in developing and evaluating the services being performed.' ${ }^{24}$ The CCRSC created a formal office called Charismatic Renewal Services (CRS), a single organization in two locations, South Bend and Ann Arbor, with distinct responsibilities - the Notre Dame / South Bend group was in charge of organizing conferences and sending out literature and promotional material, while the Ann Arbor group was responsible for publishing Servant Books, New Covenant, and the Life in the Spirit Manual. ${ }^{25}$ Fully functioning by $1970-71$, these services were early developments in structuring the CCR movement, with a primary focus on the North American experience.

These institutional structures were more a necessary practical step taken by leaders on their own initiative than an official move. In fact, the CCR was a grassroots movement with little effective leadership for many years. Agreement within prayer groups and communities was initially reached through discussion and prayer, without any kind of formal authority. However, as time went on, national leaders started to have a definable impact and exercise an important influence on the public face of the CCR, particularly in terms of ecumenism, theological direction, and spirituality. The CCRSC became a de facto organ for aligning the different expressions of charismatic spirituality, with an increasing focus on the establishment of covenant communities. In 1971 it expressed the core of its understanding of authority as follows:

The Service Committee does not claim any authority over groups or individuals involved in the charismatic renewal of the Church. Its only authority is over the services it provides, and within those services it exercises the normal supervision. Its members exercise only that authority both moral and pastoral which the Lord gives to them, and which is confirmed and accepted by fruitful service to the body ... Because the

\footnotetext{
24 'Advisory Committee Meets', New Covenant (July 1971), 7-8.

25 For early institutional structures, see Jim Byrne to Steve Clark, 8 February 1972, James E. Byrne Papers, Administrative Committee Minutes 1972, CJE B 1/o1, UnDA.
} 
charismatic renewal is a renewal (an unorganized movement) there can be no authority structure within it. The only authority can be the authority that comes from services well performed. ${ }^{26}$

This idea of an authority not formally established but pursued by way of services offered to the Church for the renewal was a key conceptual instrument in the process of validating and consolidating these organizational structures. In other words, if the Service Committee could not command, since it had no actual authority, either legally or ecclesiastically, it could nevertheless definitely influence and convince, thanks to the authority that came from all its 'well performed' services.

In the 1970s, the number of Catholic charismatic prayer groups in the United States increased significantly. As only one indication of this explosive growth, the number of participants at the annual Notre Dame conferences grew exponentially: in 1967 it was attended by about 90 people, while in 1970 by 1,500, and in 1973 by around 22,000. ${ }^{27}$ If the rapid growth called for more formal structures, it was also an opportunity to experiment with new way of religious living. In 1971, two covenant communities were established in the same geographical area - one Catholic, named True House at Notre Dame; and one ecumenical, the People of Praise in South Bend. Both groups were shaped by similar visions and initially inspired by early Christian communities and by The Word of God community in Ann Arbor. However, not enough importance has yet been given to the influence of Graham Pulkingham whose life was revolutionized by his encounter with David Wilkerson and who founded an influential charismatic community in the parish of Church of the Redeemer in Houston, Texas. The community around Church of the Redeemer soon became a charismatic pilgrimage site for the entire world, thanks to Pulkingham's healing ministry and attractive personality. ${ }^{28}$ Leaders in the CCR were eager to involve Pulkingham from the beginning, inviting him to speak at the 1969 Notre Dame conference and to collaborate with New Covenant. In connection with this interdenominational rapprochement, he visited South Bend before the foundation of People of Praise and met informally with several leaders, a key moment, at a time when the leaders were receiving strong criticism from a Notre Dame professor

\footnotetext{
26 'Advisory Committee Meets', New Covenant (July 1971), 7.

27 The Charismatic Renewal Among Catholics: Data Sheet (January 1973), in James T. Connelly Papers, CJTC 1, UNDA.

28 Julia Duin, Days of Fire and Glory: The Rise and the Fall of a Charismatic Community (Baltimore, MD: Crossland Press, 2009); Michael Harper, A New Way of Living: How the Church of the Redeemer, Houston, Found a New Life-Style (Plainfield, NJ: Logos International, 1973).
} 
of Scripture studies (analysed below). The idea of establishing a formal community was already under investigation, but Pulkingham imbued the leaders with more confidence and was helpful in showing them a different perspective, where, among other things, prophecy was more central. ${ }^{29}$ Beginning in August 1971, Ranaghan mailed out about 100 invitations to people in the local area who might be interested in praying together and discussing the formation of a covenant community. ${ }^{30}$ This provided the nucleus, and two months later 29 people established a formal covenant community, named the People of Praise in February 1972. ${ }^{31}$ In autumn 1973 the CCRSC asked the People of Praise to take responsibility for the South Bend portion of CRS, which included the conference office responsible for administration of the annual international conferences at Notre Dame.

The short-lived True House community developed along a somewhat different path. In 1968 a wealthy local businessman and motivational speaker, Herbert True, had donated the use of his former residence in South Bend as a resource for the Church. With the idea of bringing more students at Notre Dame into the CCR, Byrne and Edwards moved into the house in summer 1968, and dedicated themselves to the charismatic renewal. ${ }^{32}$ They and other student leaders, such as Tom Noe, ran a variety of student-oriented evangelistic programmes, engaged in door-to-door visitation in the university dormitories, and sponsored Antioch Weekend retreats and a regular Friday event which included a mass. ${ }^{33}$ This group soon became the base for CRS ministries such as the Communication Center and the conference office. In summer 1970, some members of this loosely connected group experienced a turning point, building up toward a more formal community. By September 1971, a group of 21 people had agreed upon a covenant (comprised of two Dominican nuns from

29 Oral memories are not unanimous, but Pulkingham probably visited South Bend between summer 1970 and summer 1971. Tom Noe, one of the leaders of the Christ the King prayer meeting and later a member of the People of Praise, visited the Church of the Redeemer and spoke with Pulkingham in summer 1969; Grace and Peace (19 August 1969), CEOC 1/ 04, UNDA.

30 Letter to Gene and Winnie (no sender), 5 August 1971, Correspondence (Apostolic Institute) 1969-73, CJEB 1/42, UNDA.

31 https://peopleofpraise.org/about/who-we-are/ (accessed 21 April 2021). See also Tom Noe, 'Notes from Early Community Meetings: September, 1971', People of Praise Vine \& Branches (September 1996), 5; 'Notes from Early Community Meetings: Making the Covenant', People of Praise Vine \& Branches (October 1996), 6-7.

32 Byrne and Edwards initially planned to join the Ann Arbor community; A Report on the Notre Dame Charismatic Community (March 1971), 10-11, True House Records [TRU], box 1, True House Weekend, UnDA.

A Report on the Notre Dame Charismatic Community (March 1971), 14. 
Racine, Wisconsin, who joined the group with official permission, seven Notre Dame students, and several non-university contacts). ${ }^{34}$ By February 1972, there were 32 members divided into seven households - three on the Notre Dame campus and four off-campus: one for married couples, one for single men, one for single women, and one for the nuns. The leadership was shared among four coordinators, and 'handmaids' and 'servants' helped the community with their daily services. ${ }^{35} \mathrm{Fr}$. O'Connor and another Notre Dame theologian, Robert Nogosek, provided formational talks and teaching on a regular basis. ${ }^{36}$ However, in 1975 the community split.

Members of the covenant communities in South Bend and Ann Arbor True House, People of Praise, and The Word of God - played a disproportionately large, and indeed crucial, role within North American Catholic charismatic leadership. They also assumed global responsibilities for promoting the CCR worldwide, with an International Communications Office (ICO) launched in Ann Arbor in $1972 .{ }^{37}$ From the beginning, a crucial point of discussion was whether there was a conflict of interest between the communities and CRS or, more generally, between the communities and the $\mathrm{CCR}$, which was composed mainly not of communities but of prayer groups and other similar entities. It was a fair question: if the CCRSC's members were for the most part leaders of covenant communities, how could the vision of a movement primarily made of prayer groups be represented? Again, if there were only three sponsoring communities, how could a plurality of approaches and visions be guaranteed as the CCR expanded? This issue was noted often in discussions, and is prominent in the correspondence of several 'guardian' figures in the movement, such as Joseph McKinney (Auxiliary Bishop of Grand Rapids, Michigan), the CCRSc's episcopal advisor, and Fr. Kilian McDonnell (director of the Collegeville Institute for Ecumenical and Cultural Research, Minnesota), the CCRSC's

34 A Report on the True House Community (February 1972), 2, TRU, box 1, True House 1972, unda. See also the covenant, The Fundamental Principles Which We Agreed Upon (15 August 1971), TRU, box 1, True House Covenant and Community Agreements, UNDA.

35 Information for guests of True House (no date), TRU, box 1, True House Description, UNDA; coordinators' working paper (1973), TRU, box 2, National Ministries of True House, UNDA.

36 A Report on the True House Community (February 1972), 3, TRU, box 1, True House 1972, UNDA. See also A Report on the True House Community (February 1972, revision July 1973), 3, TRU, box 1, Misc. Special Reports, UNDA.

37 The ICO moved to Belgium in 1976 and was renamed the International Catholic Charismatic Renewal Office (ICCRO), and then the International Catholic Charismatic Renewal Services (ICCRS). The Pontifical Council for the Laity accepted its request for papal recognition in 1993. ICCRS ceased to operate in 2019, replaced by the Catholic Charismatic Renewal International Service (CHARIS), commissioned by Pope Francis. 
theological advisor. A letter from Steve Clark and George Martin to the CCRSC and the coordinators of the three communities in November 1973 attempted to clarify the situation. It illustrated the 'fairly unique situation' between the CCRSC and the CRS on one hand, and the three sponsoring communities on the other. According to Clark and Martin, the communities had made charismatic services possible and to some degree had provided those services as outreaches of their communities. But they acknowledged that 'CRS has to be responsive to a number of needs that pull in different directions'. ${ }^{38}$ In late 1973 and early 1974 CRS was reorganized 'so that its structure might reflect more accurately the partnership' between the CCRSC and the communities, and so that 'no group has control of the corporation or any part of the corporation except through the board of directors'. ${ }^{39}$ However, correspondence between McKinney and McDonnell in August 1975 shows that representation remained a sensitive subject. McKinney wrote:

I also believe that in the renewal is a very strong orientation toward revitalizing parish structures that is not adequately reflected in the Service Committee services. If we continue to follow the present interpretation of the Catholic Ecumenical in the New Covenant and conferences with an obvious preference for covenant communities, then we should not be surprised if a new leadership emerges in the renewal. ${ }^{40}$

McDonnell answered simply:

I agree fully that more attention has to be given to parish renewal.... I do think that the Service Committee does not sufficiently represent the interests and outlook of prayer groups which are parish orientated. Covenant communities have an important contribution to make to the renewal but there should be a pluralism in the way the renewal is expressed. ${ }^{41}$

It is clear that the members of these Midwest communities not only played a crucial role in shaping the renewal as a whole, particularly in its delicate initial

38 Steve Clark and George Martin to the coordinators of the People of Praise, True House and The World of God, 26 November 1973, TRU, box 2, CRS - True House Relations, UNDA.

39 Charismatic Renewal Services, Archives of Diocese of Grand Rapids [ADGR], file 1-283, McKinney, Joseph C.

40 Joseph Kinney to CCrsc members, 13 August 1975, ADgr, file 1-283, McKinney, Joseph C.

41 Kilian McDonnell to Joseph McKinney, 25 August 1975, ADgr, file 1-283, McKinney, Joseph C. 
phase, but also that the proclaimed 'loose structure', with no formal authority, seemed to be in reality more selective than inclusive. Although in their self-representation leaders depicted themselves as individuals chosen by the Holy Spirit to guide the renewal in a democratic way, the urgency for social and ecclesiastical legitimization and the need for a certain degree of uniformity created very soon a directive structure, managed by few people oligarchically. Eventually, Cardinal Suenens's role in moving the ICO to Brussels in 1976, and further disagreement among the covenant communities, alongside increased global interconnectivity and ease of travel, intensified the need to rethink about the structure and the leadership of the CCRSC, transforming it into something different, a service committee with small-scale national purposes. ${ }^{42}$

\section{3}

\section{Facing Criticisms}

The prominent role of Catholic charismatic communities and the nature of their authority were never exempt from criticism, even from within. Several theologians wrote about dangers that the CCR could face. ${ }^{43}$ For example, the Dominican theologian Simon Tugwell perceived among Catholic charismatics a tendency to be an 'A group', that is an exclusive and elitist group, and that 'belonging to the Group, to the Movement, becomes an end in itself'. He warned against a sort of 'spiritual unreality', linked only to certain externals such as shared prayer or charisms, and thus over-objectifying the Holy Spirit experience. ${ }^{44}$ In the same way, the American bishops' statement, Pentecostal Movement of the Catholic Church in the United States (1969), although overall favourably disposed, warned about elitism, sensationalism, emotionalism, biblical fundamentalism, and leaderism. ${ }^{45}$ Indeed Kevin Ranaghan himself

42 CCRSC minutes, 13-14 May 1976, where CCRSC was renamed National Service Committee of the Catholic Charismatic Renewal of the United States (informally NSC), Sword of the Spirit Archives, www.swordofthespirit.net/history-catholic-charismatic-renewal/, CCRSC minutes (accessed 21 April 2021).

43 For example, Henri J. M. Nouwen, 'The Pentecostal Movement: Three Perspectives', The Scholastic (21 April 1967), 15-17, 32; Patrick L. Bourgeois, Can Catholics Be Charismatic? Fundamentals of the Full Christian Life (Hicksville, NY: Exposition Press, 1976), 85-98; James Hitchcock, The New Enthusiasts and What They Are Doing to the Catholic Church (Chicago: Thomas More Press, 1982), 123-33.

44 Simon Tugwell, Catholic Pentecostalism: An Evaluation (London: Catholic Truth Society, 1973), 14.

45 Kilian McDonnell (ed.), Presence, Power, Praise: Documents on the Charismatic Renewal, vol. 1 (Collegeville, MN: Liturgical Press, 1980), 209-10. See also the special issue on 
published a booklet in 1973 exploring a variety of both positive aspects and negative attitudes within the CCR. He referred to 'symptoms' of what he called 'come-out-ism', namely, the tendency of groups of enthusiastic Christians to separate themselves from their 'parent' church through the use of a vocabulary that sounded unfamiliar to Catholics (mainly because it derived from classical pentecostalism and neo-pentecostalism), considering non-charismatic Catholics to be unsaved or second-class, and believing prayer groups or covenant communities to be the true 'spiritual' Church, while rejecting teaching and preaching from non-charismatics. ${ }^{46}$

As part of the theological debate on the Holy Spirit and charismatic spirituality within the tradition of the Catholic Church, the work of Josephine Ford soon appeared. She was a Scripture professor at Notre Dame from 1965 , having earned her doctorate in her native England, and was the first female faculty member to achieve a tenured position at the university. ${ }^{47}$ Her early publications on the CCR included The Pentecostal Experience (1970) and Baptism of the Spirit (1971). In a later volume, Which Way For Catholic Pentecostals? (1976), she classified two pentecostal types - type I had a para-ecclesial structure, a teaching advisory, an executive magisterium, and a discipline system (such as Church of the Redeemer, The Word of God, and People of Praise); type II was flexible and less structured, fully integrated with the theology and sacramentality of the Church, open to non-pentecostal influences, and deeply interested in Eastern Orthodox theology. Structuredness, authoritarianism and the tendency to lose Catholic identity were listed as the foremost of a number of dangerous issues for the Catholic charismatics and indeed for the church as a whole. ${ }^{48}$

Ford had initially been attracted by the charismatic spirituality in evidence at the early prayer meetings at Notre Dame / South Bend in 1967 and started attending regularly. However, she soon began publicly to criticize attitudes such as a schismatic trend and a misogynistic approach. After a series of misunderstandings with charismatic leaders - the two most dramatic moments

the bishops and the charismatic renewal in New Covenant (September 1971), particularly 'Report of the American Bishop' and 'Interview with Bishop Joseph McKinney', 7, 10-16.

46 Kevin Ranaghan, The Lord, the Spirit and the Church: A Prominent Leader Examines Attitudes Toward Charismatic Renewal in the Church (Notre Dame, IN: Charismatic Renewal Publications, 1973).

47 Ford's 2015 obituary is at https://news.nd.edu/news/in-memoriam-josephine-massyngbaerde-ford-professor-emerita-of-theology-at-notre-dame/ (accessed 21 April 2021).

48 J. Massyngberde Ford, Which Way For Catholic Pentecostals? (New York: Harper and Row, 1976). 
occurring during the second and third Notre Dame conferences, when she interrupted the proceedings in order to attack the charismatic leadership the CCRSC decided to refuse her registration application for the 1971 Notre Dame conference and issued a public explanation of its decision. The CCRSC suggested the issue was not 'one of theological opinions', but 'whether or not someone is willing to act in accord with some kind of order and decorum', perceiving Ford as a 'source of division and disruption'49 Although she finally attended the conference and was not asked to leave, her vehement and constant critiques (published and verbal) in the following years represented a heavy burden for the development of both the university and city charismatic prayer groups and communities. ${ }^{50}$ Ford not only disrupted prayer meetings and other events, and ran into conflicts with her colleagues in the Theology Department, including Fr. O'Connor, but she also addressed letters to bishops and administrators within the University of Notre Dame trying to gain a hearing and some form of approval for her views. As an example of her efforts, in May 1972 she wrote to Bishop Pursley asking him to use his authority to establish a panel of Scripture scholars to conduct a workshop during the 1972 Notre Dame charismatic conference. In describing his attitude towards the CCR, expressed on other occasions, the bishop showed his reluctance to intervene personally in the conference plan, for 'I want to avoid any action which could tend to identify me publicly with the movement.'.1 In 1971 Ford also sent her critical articles regarding the movement to Alexander Zaleski (Bishop of Lansing, Michigan), reiterating that the Catholic pentecostal movement needed a closer association with the established ministry (namely, the ecclesiastical hierarchy) and a sound theology. She warned about a local deacontraining centre (the Apostolic Institute, founded in 1969 in Fort Wayne-South Bend diocese), and about the risk of exclusivism, sectarianism, divisiveness,

49 'Statement by the Catholic Charismatic Renewal Service Committee concerning the refusal of registration at the fifth international conference on the Charismatic Renewal in the Catholic Church to Dr Josephine M. Ford' (1971), CEOC 1/33, UNDA. See also Jim Byrne to Josephine M. Ford, 8 June 1971, CEOC 2/O2, UNDA; CCRSC minutes, 21 June 1971, Sword of the Spirit Archives. For a news report, see Dolores Liebeler, 'Exclude N.D. Theologian From Church Conference', South Bend Tribune (16 June 1971).

50 Wayne Falda, 'Conference on Charismatic Renewal of Church Opens', South Bend Tribune (19 June 1971), 7 .

51 Leo Pursley to Josephine M. Ford, 19 May 1972, CEOC 2/o1, UnDA. For the initial US ecclesiastical reactions towards the CCR, see Valentina Ciciliot, 'The Origins of the Catholic Charismatic Renewal (CCR) in the United States: Early Developments in Indiana and Michigan and the Reactions of the Ecclesiastical Authorities', Studies in World Christianity 25 (2019), 250-73. 
psychological manipulation of candidates, an exclusively male leadership, para-clericalism, and monopoly of leadership. ${ }^{52}$

The controversies generated by Ford also shed light on the fragile relationship between the early Catholic charismatic community and University of Notre Dame administration. Immediately after the 1971 Notre Dame conference, the university's president, Fr. Theodore Hesburgh, 'approached Fr. O'Connor about the treatment of Dr Ford'. He was not interested in the controversy between them, but 'in the tactics and effects' and pointed out that if other similar incidents were to occur, the charismatics would have to leave the campus. Likewise, James L. Shilts, chaplain of the university, felt it was a matter of scandal and 'would like to exclude the Pentecostals from campus'. 53 The preservation of the university's reputation and of the harmony among faculty members seems also to have been a priority in 1972, when Ford's participation at the conference was tabled again. When O'Connor reported to the CCRSC Hesburgh's earlier warning that if they prevented Ford from attending the conference, charismatics would not be allowed to use the facilities at Notre Dame for the future, ${ }^{54}$ 'it was decided to allow her to register but to otherwise ignore her insofar as possible', while still stressing the fact that 'this decision follows a careful study of all the options possible in this very complex situation and represents the lesser of several evils. This should not be considered as a policy-setting decision. ${ }^{55}$ Over time, Ford's strident tones decreased as the Notre Dame-South Bend communities consolidated their position within the Church and within the broader CCR as well.

Because of the annual conferences, many charismatics around the United States strongly associated the CCR with the University of Notre Dame. This was of some concern to the university, but administrators were generally pragmatic in allowing charismatic students freedom in their activities as they related to campus, and tolerated them. ${ }^{56}$ Dealing with public (and in some

$5^{2}$ Memorandum from Fr. Robert Lunsford (pastor of St Thomas the Apostle, Ann Arbor, special diocesan liaison to The Word of God community) to Alexander Zaleski, 27 August 1971, Archives of Diocese of Lansing: Bishop Zaleski, NСсв Committee on Doctrine, Dr Ford Articles, Pentecostal Movement. CCRSC minutes, 16 August 1971, Sword of the Spirit Archives.

54 CCRSC proposal, 16 March 1972, CEOC 2/O1, UNDA.

55 CCRSC minutes, 16 March 1972, Sword of the Spirit Archives.

$5^{6}$ Oral memories disagree on the level of toleration, and some people remembered an initial ostracization, particularly from members of the Holy Cross Congregation such as Fr. James Tunstead Burtchaell, provost of the University of Notre Dame from 1970 to 1977. Recorded conversations with Jill and John Boughton (11 May 2018) and Philip Sutton (12 May 2018). 
ways academic) controversies such as those raised by Josephine Ford was a different matter. The situation outlined above demonstrates that a certain amount of negotiation was involved behind the scenes with regard to the continuing presence of the annual charismatic conferences at the university, and in this sense the university's stance was fundamental for the legitimization of the CCR in general. It is also clear that Ford's continuing interventions not only complicated, but weakened, the whole negotiation process. The weight of Hesburgh's intervention is quite clear. These tensions were also part of a wider debate on the legitimacy of the movement within the Catholic Church and the University of Notre Dame, which on the one hand did not want to appear closed to new forms of Catholic experiences, but on the other hand wanted to avoid being recognized as charismatic, as later happened, for example, at the Franciscan University of Steubenville, Ohio. ${ }^{57}$

Michael Harper wrote in an insightful summary in 1979:

Kevin Ranaghan in South Bend and Ralph Martin with a number of able lieutenants seemed to have from the very beginning a deft touch in steering the renewal through some pretty tricky waters. It has been able to maintain an enthusiastic Pentecostal surge, while avoiding the worse features of fanaticism or a limp scholasticism. It was kept in tune with many of the vibrating chords of the American religious tradition, and so from the beginning has always been a popular movement. At the same time, it has gone out of its way to keep in range of the hierarchy, and to seek its approval wherever possible. ${ }^{58}$

Although the Notre Dame / South Bend and Ann Arbor charismatic communities were not the sole source of leadership for the early CCR - one thinks for example of the impact of the Benedictine monastery in Pecos, New Mexico, as another place of charismatic formation, or Fr. Francis MacNutt and Fr. Favian Osowski as people who were prominent figures during its initial development - yet leaders in Indiana and Michigan played a unique role in shaping

57 Margaret M. Grubiak, "Visualizing the Modern Catholic University: The Original Intention of "Touchdown Jesus" at the University of Notre Dame', Material Religion: The Journal of Objects, Art and Belief 6 (2010), 336-68. 
the Catholic charismatic movement as a whole. It was in the Upper Midwest that the earliest formal structures were established, paving the way for exponential growth on a global scale. The North American Catholic charismatic leadership influenced the Catholic charismatic movement on two fronts. On the one hand, it coordinated the CCR at the national level in the United States and in Canada, determining its main characteristics, above all in the momentum of building covenant communities, in addition to prayer groups. On the other hand, it sought from the beginning some legitimization by the ecclesiastical hierarchy, which allowed the entire movement to integrate itself to some degree within the Catholic Church, thus endorsing the movement in a way that eased its spread to other continents. As a matter of fact, the initial reactions of the Catholic bishops to the renewal in the United States, in 1969 and then in 1975, encouraging it and warning about it at the same time, helped its successful development. Inevitably, this early institutionalization, driven mainly by the need for a spiritual and doctrinal uniformity, caused a certain tightness to develop in procedures and approach, which became more constraining over time. In other words, if the CCR was born as a movement from below, within a relatively short time its grassroots base was joined by an influential and well-prepared lay leadership able to respond to grassroots requests and satisfy them, but also to transform them to its own purposes. A similar process of institutionalization occurred in other Christian charismatic experiences. Certainly, the North American Catholic charismatic leaders deeply shaped the CCR from the very beginning, providing it with structures and paradigms that helped it to expand globally.

Emerging clearly from this historical analysis is the fact that the origin of the CCR was influenced by several equally important factors: a self-reliant laity, a search for spiritual renewal that arose in the late 196os both in American culture and in the post-Vatican II Catholic Church, and grass-roots interactions among Christian denominations involved in charismatic renewal. The form assumed by the Catholic charismatic movement was a product of the unique cultural, religious and social context of the 196os United States, but it would soon begin to confront the Catholic Church as a whole. 